\title{
The Nexus of Macroeconomic Policy and Entrepreneurship Performance in West Africa
}

\author{
Akinseye Olowu ${ }^{1}$ \\ Edwin ljeoma ${ }^{2}$ \\ Annabel Vanroose ${ }^{1}$ \\ ${ }^{1}$ University of Stellenbosch Business School, \\ Bellville 7530, Cape Town, South Africa \\ ${ }^{2}$ School of Government \& Public Administration, \\ University of Fort Hare, South Africa
}

Doi: 10.36941/ajis-2019-0024

\begin{abstract}
This study examined the effect of selected public policies on entrepreneurship activities in the anglophone and francophone divides of West Africa to determine the nexus of performance using several analytics techniques. The data used were obtained from secondary sources originating from institutional organisations in ten selected countries from the 2000 to 2018. An institutional framework for entrepreneurship indicators was adopted as a measure for entrepreneurship in the region otherwise known as TEA. Using the ARDL analysis on the cross sectional data, the empirical evidence reveals that, while monetary policy was more significant in promoting TEA in Anglophone countries, fiscal policy did better in the francophone countries. The study recommends that governments should harness, formulate and execute the best of monetary and fiscal policies in West African countries. The contribution of the private sector partnership in the drive to 'promote entrepreneurship should also be encouraged in such a way that the economies in the countries aim towards innovative and efficiency competitiveness in democratic societies.
\end{abstract}

Keywords: TEA, monetary policy, fiscal policy, performance, West Africa

\section{Introduction}

Macroeconomic policies have a wide and deep history in West African countries. However, due to the different peculiarities of the business environments, the macroeconomic stance and objectives differ from country to country. The macro environment, often used interchangeably with external environment, encompasses variables that are not within the control of the entrepreneur. Entrepreneurship scholars have identified several of these external variables. For instance, principal among the factors identified are the influences of the markets (Thorntorn, 1999); public policy is a key determinant, as entrepreneurship opportunities exist in business environments regulated by government (Baumol, 1990; Dobbin \& Dowd, 1997); and the role of physical infrastructures cannot also be overemphasised (Agboli \& Ukaegbu, 2006). The forces that operate within the macro/external environment are of paramount importance to entrepreneurship because the knowledge of the environment helps the entrepreneur identify conditions that may impede the progress of the business and, therefore, plan ahead to forestall such occurrence.

Historically, the monetary policy in Africa has evolved over the past decades, contributing to a rich economic history. According to Honohan and O'Connell (1996), it has metamorphosed through 
the following stages: (i) Currency Board which economises on the use of currency that was operational both in English-speaking and French-speaking countries in the 1960s; (ii) Printing Press which responded passively to domestic and external shocks by managing money supply; (iii) Rationing Regime which controlled prices of goods and services, labour market wages, and also controlled interest rates and the exchange rates; (iv) Credit-Ceiling Regime which this was an economic reform programme used to ration access to borrowing; (v) Market-Clearing Regime which paved the way for modern central banks operating in a market-based economic and financial system where the government can only borrow from the central bank at market rates determined just like for any other borrower, and all seigniorage revenue vanishes. Indeed, the stability and efficiency of the financial sector, especially the banking system, has become a major concern for central banks in all economies (Ncube, 2015). For instance, the questions of whether government budgeted deficits are inflammatory and why central bankers worry about government budgets, have been arguably found to depend on how the monetary and fiscal policies are interacted. Hence, having stable and low inflation requires proper coordination of fiscal and monetary policies in every economic management endeavour. Achieving low inflation, as well as high and sustained output depending on the monetary framework, is a cardinal function of central banks in engendering economic growth. The degree of the central banks' independence is in performing its functions; notwithstanding, there is a high level of interdependence with the fiscal authorities and actions. Concerning effectiveness of the monetary policy vis-a-vis its statutory macroeconomic goals, there exist a large quantum of both theoretical and empirical studies (Taylor, 2004; Sims, 1994, 2007; Gali \& Gertler, 1999; Gali et al., 2012). Despite the wide volume of literature that central bank independence and monetary policy are positively correlated, the monetary policy is not and can never be isolated from other economic authorities such as fiscal policy in its role of promoting entrepreneurship.

On the other hand, the fiscal policy actions, responses and overall well-being of citizens have been found to be positively related to entrepreneurship growth (Gali, 2008; Hermawan \& Munro, 2008; Monacelli, 2004) and this implies that when fiscal discipline is ensured, price management may become convenient. In other words, government effort at improving economic welfare could be either be entrepreneurship enhancing or inhibiting depending on its policies. According to Dennis (2005), 'a common criticism of policies geared towards entrepreneurship is that of a re-inventing wheel, or a poor accumulation and sharing of knowledge and experience'. Despite the wide range of policy measures implemented to accelerate economic growth, the empirical evidence on the relationship between macroeconomic policies, central banks' operations and entrepreneurship performance remain unresolved. This study attempted to answer this in order to contribute knowledge to the studies on national entrepreneurship in West Africa.

\section{Macroeconomic Variable Specification}

\subsection{Monetary policy instruments:}

(i) Money supply: This represents the total amount of money in circulation in a country controlled by its apex bank, commonly known as the central bank. This causes changes in national income. The broad money supply $\left(\mathrm{m}_{2}\right)$ was used as the variable for this study. The supply of money into a market system affects both demand-side and supply-side conditions conducive for entrepreneurship (Harper, 2003). The availability of money supply empowers entrepreneurs to participate in entrepreneurial activities

(ii) Inflation: Inflation was calculated by using the consumer price index. Higher inflation was expected to reduce real credit growth. The nominal interest rate on bank loans is typically fixed. Therefore, high inflation rates lower the real return on assets earned by the borrower, i.e. the bank. High inflation rates complicate credit adverse situations (Boyd \& Champ, 2003). This reduces the access to finance for entrepreneurship activities.

(iii) Interest rate: This variable represents the cost charge on the credit facilities offered by the commercial banks. High interest rates reduce access to finance as entrepreneurs will not be able to afford getting loans from banks for entrepreneurship purposes, because of the 
increase in the cost of a loan. If the interest rate on the loan is reduced, entrepreneurs will be able to borrow enough funds for production. However, a low interest rate is an incentive for loan borrowers; it will encourage more investments in entrepreneurship activities. Hence, entrepreneurship activities will increase because the cost of finance is reduced. Thus, overall, an inverse relationship between entrepreneurship performance and interest rate is expected.

(iv) Inflation: The rate of inflation in countries reduces the purchasing power of a local currency. It creates a situation whereby there is an excess supply of money in circulation chasing few goods. Inflation rate determines the value of a local currency when compared to other currencies. Given that inflation lowers the purchasing power of entrepreneurs, the demand for production inputs will fall when inflation is high. Therefore, a negative relationship is expected between entrepreneurship performance and inflation rate.

(v) Exchange rates: This variable represents the exchange rate value of the local currencies of countries against a foreign currency. In this case, the exchange rate of the United States dollar was used. The variable could have a dual effect on entrepreneurship in countries. The variable could either enhance or mar entrepreneurship activities depending on the movements of the local currency against the US dollars. For instance, if the local currency appreciates, entrepreneurs will be able to import raw material from abroad for production purposes, but at the same time, the situation makes the export of locally produced goods expensive at international markets, and vice-versa.

\subsection{Fiscal policy instrument:}

(vi) Government expenditure on infrastructure: Development economists acknowledge the centrality of public expenditure, particularly on infrastructure, as an important instrument in the development process (Edame \& Fonta, 2013). For instance, entrepreneurship tends to grow when there are good road networks, an effective telecommunication system and regular power supply. However, expenditure on infrastructures is capital intensive and it is one of the main considerations of a financial budget. Government expenditure on infrastructure has been an issue for policy discourse among scholars the world over. Sanchez-Robles (1998), Aschauer (1989), Adenikinju (2005), and Agenor and Dodson (2006).

\subsection{Other factor that drive entrepreneurship at national level:}

This variable is peculiar to countries in West Africa.

(vii)Election year (political variable): Due to the political history of West Africa, which has been highlighted in previous chapters, this variable was of interest to this study. The gloomy picture of politics and elections have implications for entrepreneurship in the region. For instance, Braconier and Holden (2004) asserted that the occurrence of election in a country is associated with fiscal expansion through lower taxes. Likewise, the theory of the political business cycle suggests that fiscal policies tend to become more expansionary during election years.

\section{Data Analysis}

Not many studies have investigated the relationship between macroeconomic policies and entrepreneurship at cross-country level. However, the few that exist regress a measure of entrepreneurship on policy instruments along with other control variables. The recognition of entrepreneurship as a driver of economic growth has led policy analysts, researchers and economic theoreticians to improve on the measurement of entrepreneurship at national level. For instance, at an international level, programmes by the World Bank, Eurostat and private organisations such as GEM have developed internationally comparable data (Ahmad \& Hoffman, 2007). Therefore, the entrepreneurial activities in countries was adopted for this study as the dependent variable 
measured by TEA as measured by the GEM minus innovation measures and given the peculiarities of availability of data. This is beacuse it is impossible to adopt the full indicators of entrepreneurship activities as measured in previous studies, GEM and the knowledge economy indicators. However, this study adopted a specific TEA using the OECD indicators in Ahmad and Hoffman (2007) along with some indicators of GEM and the knowledge economy. From the study, three cardinal points were adopted to measure entrepreneurship: (i) the determinant of entrepreneurship which was adopted from R\&D \& Technology, i.e. innovative potentials; (ii) the entrepreneurship performance which was adopted revenue from export, domestic private investment and equity portfolio; and (iii) entrepreneurship impact measured by economic growth and job creation.

Thus, given the focus of this study, a dynamic cross-country panel data approach was applied to explain the effects of the macroeconomic policies on entrepreneurship in West African countries using annual data from 2000 to 2018. The secondary data comprised 19 years' range and 2280 data points on panel. This helped to validate the robustness of the analysis, as well as to minimise biasness in the result to be generated. The baseline model was as follows:

$K=f(G, C V)$

where:

$\mathrm{K}=$ Total entrepreneurship index (TEA)

TEA = Level of entrepreneurship activity

$\mathrm{G}=$ Vector of explainable variables reflecting fiscal and monetary policy instruments

$\mathrm{CV}=$ Control variable

In this study, the effect of fiscal and monetary policies on entrepreneurship was measured in the selected anglophone and francophone countries in West Africa. The study deviated from the previous estimation used in examining the effects of public policies on entrepreneurship in the previous study by using the robust econometric technique of autoregressive distributed lag (ARDL) proposed by Shin, Yu and Greenwood-Nimmo (2014) on panel data to examine the strength of monetary and fiscal instruments in determining entrepreneurship levels. This method is superior to other methods such as the error correction model (ECM), threshold ECM, Markorv-switching ECM in modelling joint cointegration dynamics and asymmetries. The ARDL method makes estimation possible even when explanatory variables are endogenous. Unlike the ECM, the ARDL is used even when the variables are cointegrated at first level or fractionally cointegrated and when the variables have a different number of lags. The ARDL model also allows the joint analysis of the issues of non-stationarity and nonlinearity in the context of an unrestricted error correction model (Katrakilidis \& Trachanas, 2012).

The general form of the ARDL model is considered below:

$\Phi(L) y_{t=} \alpha_{0}+\alpha_{1} W_{t}+\beta^{\prime}(L) \mathbf{X}_{i t}+\mu_{t}$

Where $\Phi(L)=1-\sum_{i-1}^{\infty} \Phi_{1}\left(L^{i}\right), \beta(L)=\sum_{j=1}^{\infty} \beta_{j}\left(L^{j}\right),(L)$ is the lag operator, $W_{t}$ is a vector of deterministic variables such as intercept, seasonal dummies, time trend or other exogenous variables with fixed lags. This model uses negative and positive partial sum decompositions, which enable one to detect asymmetric effects in the short and long run. The following nonlinear asymmetric cointegration regression is considered as:

$y_{t=\beta^{+}} x_{t}^{+}+\beta^{-} x_{t}^{-}+W_{t}+\mu_{t}$

Where $\beta^{+}$and $\beta^{-}$are long-run parameters and $x_{t}$ is a $k \times 1$ vector of regressors expressed as follows: $x_{t}=x_{0}+x_{t}^{+}+x_{t}^{-}$

Where, $\quad x_{t}^{+}$and $x_{t}^{-}$are negative and positive changes on partial sum

$x_{t}^{+}=\sum_{j=1}^{t} \Delta x_{j}^{+}=\sum_{j=1}^{t} \max \left(\Delta x_{j}, 0\right)$ and $x_{t}^{-}=\sum_{j=1}^{t} \Delta x_{i}^{-}=\sum_{j=1}^{t} \min \left(\Delta x_{j}, 0\right)$

processes in $x_{t}$ : (AECM)

Combining equation 2 and the $\operatorname{ARDL}(\mathrm{p}, \mathrm{q})$ we generate an asymmetric error correction model

$$
\Delta \mathrm{y}_{t}=p y_{t-1}+\theta^{+} x_{t-1}^{+}+\theta^{-} x_{t-1}^{-}+\sum_{j=1}^{p-1} \varphi_{j} \Delta y_{t-j}+\sum_{j=0}^{q}\left(\pi_{j}^{+} \Delta x_{t-j}^{+}+\pi_{j}^{-} \Delta x_{t-j}^{-}\right)+e_{t}, j=1, \ldots, q
$$

Where, $\theta^{+}$is $-p \beta^{+}$and $\theta^{-}=-p \beta^{-}$

The researcher performed the analysis by using the following function:

$Y_{i t}=\alpha Y_{i t-1}+\beta(L) X_{i t}+\mu_{i}+\varepsilon_{i t,}|\alpha| \prec 1, i-1, \ldots, N ; t=1, \ldots, T$

where $Y_{i t}$ is the dependent variable representing total entrepreneurship activities 
indicators, $\beta(L)$ is the $1 * k$ lag polynomial vector, $X_{i t}$ is the $k * 1$ vector of explanatory variables other than the $Y_{i t-1}, t$ is time, $i$ is the cross-sectional dimension respectively, $\mu_{i}$ is the unobserved heterogeneity and $\varepsilon_{i t}$ is the error term. The difference transformation of equation 5 was first applied to make it possible to eliminate the macroeconomic policies effects in both categories of economies.

$\Delta Y_{i t}=\alpha \Delta Y_{i t-1}+\beta(L) \Delta X_{i t}+\Delta \varepsilon_{i t}$,

With $\Delta$ as the first difference operator. Equation 7 included the following variables:

$\Delta T E A_{i t=} \alpha_{0}+\alpha_{1} T E A_{t-1}+\alpha_{2} F P_{t-1}+\alpha_{3} M P_{t-1}+\alpha_{4} E P_{t-1}+\sum_{i=1}^{3} \alpha_{5 \iota} \Delta T E A_{t-1}+$

$\sum_{i=1}^{3} \alpha_{6 \iota} \Delta F P_{t-1}+\sum_{i=1}^{3} \alpha_{7 \iota} \Delta M P_{t-1}+\sum_{i=1}^{3} \alpha_{8 \iota} \Delta E P_{t-1}+\varepsilon_{i t}$

Where $\Delta$ and $\varepsilon_{\text {it }}$ are the first difference operator and the white noise term respectively. The ARDL bound test approach for the long-run relationship between TEA and its determinants is based on the Wald statistics or F-statistics. ARDL follows the estimation of the regression but chooses an appropriate lag length using the Akaike Information Criterion (AIC). It imposes restrictions on the long-run estimated coefficients of one lagged period of TEA, MP, FP and EP to be equal to zero, which is $H_{0}: \alpha_{1}=\alpha_{2}=\alpha_{3}=\alpha_{4}=0$. Pesaran et al. (2001) assumed the explanatory variables to be integrated of order zero, that is, I(0) for values of the lower bound while an integration of order one, i.e. I(1) is assumed for upper values. Based on the Pesaran et al. (2001) decision rule, if the computed $F$ statistic exceeds the upper bound value, then it can be concluded that TEA and its determinants are cointegrated. On the other hand, should the computed $F$ statistics fall below the lower bound value, then reject the null hypothesis (no cointegration. Thus, specifying the short-run dynamics of the bound test using the error correction model (ECM), results in:

$$
\triangle T E A_{i t=\alpha_{0}}+\sum_{i=1}^{4} \alpha_{1 \iota} \Delta T E A_{t-1}+\sum_{i=1}^{2} \alpha_{2 \iota} \Delta F P_{t-1}+\sum_{i=1}^{2} \alpha_{3 \iota} \Delta M P_{t-1}+\sum_{i=1}^{2} \alpha_{4 \iota} \Delta E P_{t-1}+
$$

$\alpha_{5} e c m_{t-1}+\varepsilon_{i t}$

$\mathrm{ecm}_{\mathrm{t}-1}$ in the above equation long-time lagged residual term depicts the disequilibrium in the long run while $\alpha$ represents the rate of change of each variable in equation (12).

\section{Result}

The mean value of TEA over the period was $1.89 \mathrm{e}+08$ with standard deviation of $9.21 \mathrm{e}+08$. This implies that the data were not normally distributed over the periods as a result of wide variation in the values. The minimum and maximum values of TEA were 11598.62 and $9.96 \mathrm{e}+09$ respectively. The behavior of money supply showed that the ranges from 5.21006 to 54.94486 as minimum and maximum values respectively. The mean value was 26.11378 with a standard deviation of 9.290927 and this indicated that the data were normally distributed over the periods under this study. Again, examining the behavior of interest rate, it was shown that the average value was 12.72949 with standard deviation of 8.722722 . The minimum and maximum values of interest rate were 2.8 and 40.56 and it is an indication that the variable was not normally distributed over the periods. inflation had an average value of 6.697251 with standard deviation of 6.275125 and this indicated that the data were not normally distributed over the periods. The values range from 0.051997 to 35.83668 as minimum and maximum values respectively. About 678.6527 was estimated as the mean value of exchange rate and its standard deviation was 1156.938 which showed that the variable was not normally distributed over the periods. It has a minimum value of 0.5449192 and maximum value of 7384.432 over the periods. On government expenditure on infrastructure, the minimum and maximum values were 3.243096 and 34.85998 respectively, while the mean and standard deviation values were 19.36686 and 6.867205 respectively. The value of standard deviation confirms that the data were not far from the mean and this showed that the variable is normally distributed over the periods. All the variables discussed above were measured as continuous variables but election was measured as a dummy variable. It was coded as $\mathrm{E}$ and $\mathrm{N}$ and represented in the analysis as 1 and 0 respectively. The average value of election was 0.1894737 with standard deviation of 0.3929198 and ranges from 0 to 1 as minimum and maximum value respectively. Despite wide disparity, it was shown that they were no regular elections across the countries during the period. 


\subsection{ARDL regression in francophone and anglophone countries}

In the long run, INF, EXR and GEI were statistically significant at $5 \%, 1 \%$ and $5 \%$ levels respectively in Francophone countries, while IR, INF, GEI and EP were statistically significant at $1 \%, 1 \%, 5 \%$ and $1 \%$ levels respectively under Anglophone countries. Also, IR was significant and positive under Anglophone but negative and not significant under francophone. This showed that $1 \%$ increase in IR in Anglophone will increase TEA by $0.21 \%$. Variable INF was statistically significant at $5 \%$ and $1 \%$ levels with positive and negative coefficients in both Francophone and Anglophone countries respectively. A unit increase in the value of INF will lead to increase in TEA by about $0.12 \%$ in Francophone but decrease in TEA by $0.61 \%$ in Anglophone. The coefficient of EXR was not significant under Anglophone but statistically significant under Francophone and this implied that a unit increase in EXR, ceteris paribus, will increase TEA by $0.0013 \%$ in Francophone. There is positive and significant relationship between GEI and TEA in both Francophone and Anglophone countries. A unit increase in GEI will increase TEA by $0.20 \%$ and $5.41 \%$ at significant levels of $5 \%$ and $1 \%$ respectively. The coefficient of EP was positive and statistically significant under Anglophone but negative and not significant under Francophone. This implied that under Anglophone, conducting election will statistically increase TEA than when election is not conducted in the long run ceteris paribus.

The short run dynamic coefficients associated with the long-run cointegration relationships were obtained from the analysis of Error Correction Model (ECM) based on ARDL panel data approach for the regions (Francophone and Anglophone). The results of the short run coefficients of ARDL are $(2,1,1,1,1,1,1)$. In the short run results, the error correction term for both Francophone and Anglophone experienced negative coefficients $(-0.198$ and -0.367$)$ and they are significant at $1 \%$ and $5 \%$ respectively. This means that there is a long run causality running from independent variables to dependent variable in both regions. It means that the system corrects its previous period disequilibrium at an adjustment speed of $19.8 \%$ and $36.7 \%$ annually across the regions.

\section{Discussion}

The empirical findings demonstrated that there was short run relationship among the variables. It was shown that all the variables under Francophone had negative coefficients except MS and EP in the short run. MS, INF and EP had negative coefficients while IR, EXR and GEI had positive coefficients under Anglophone. Statistically, IR was significant at $5 \%$ level under Francophone and this implied that $1 \%$ increase in IR will decrease TEA by $1.79 \%$ in the periods. Again, INF were significant at $1 \%$ and $5 \%$ under Francophone and Anglophone and this indicated that a unit increase in the value of INF will lead to $2.63 \%$ and $2.81 \%$ decrease respectively in TEA ceteris paribus. Likewise, EXR was significant at $5 \%$ apiece with positive and negative coefficients in both Francophone and Anglophone respectively. This showed that a unit increase in the value of EXR will decrease TEA by $0.75 \%$ in Francophone but will increase TEA by $0.80 \%$ in Anglophone ceteris paribus. GEI only significant under Francophone but negatively associated with TEA. It means a unit increase in its value under Francophone will lead to a reduction in TEA by $1.02 \%$, all things being equal. Again, EP was only significant at $10 \%$ level but negatively associated with TEA under Anglophone. This implied that in the short run, observing elections in Anglophone will reduce TEA by $0.57 \%$ than not conducting election, all things being equal.

\section{Conclusion}

The ARDL result found that the money supply in the francophone divide during the period had a positive relationship with entrepreneurship activities, thereby confirming that monetary policy impacts entrepreneurship more in the francophone divide rather the fiscal policy. Perhaps, the central bank, regional integration, common currency is to the advantage of the entrepreneurship in the divides have been instrumental to entrepreneurship development. Monetary policy acts as an important instrument for accelerating entrepreneurial development by influencing both cost of and availability of finance, controlling inflationary pressures and by maintaining balance of payments 
equilibrium in countries. An ideal monetary policy suitable for entrepreneurship activities should be able to provide an elastic credit supply to meet the requirements for expanding the monetised sector (Jhingan, 1989). As such, monetary policy stimulates entrepreneurship development. The supply of money into a market system affects both demand-side and supply-side conditions conducive for entrepreneurship (Harper, 2003). The availability of money supply empowers entrepreneurs to participate in entrepreneurial activities

On the other hand, the government expenditure on infrastructure in the anglophone divide had positive relationship with entrepreneurship activities during the period. This is justified by the numerous entrepreneurship development initiatives enacted mostly by government to drive entrepreneurship dating back to the 1960s. However, development economists acknowledge the centrality of public expenditure, particularly on infrastructure, as an important instrument in the development process (Edame \& Fonta, 2013). Entrepreneurship tends to grow when there are good road networks, an effective telecommunication system and regular power supply. However, expenditure on infrastructures is capital intensive and it is one of the main considerations of a financial budget. Government expenditure on infrastructure has been an issue for policy discourse among scholars the world over. Sanchez-Robles (1998), Aschauer (1989), Adenikinju (2005), and Agenor and Dodson (2006). Nevertheless, the role of government influencing investment is a very important function of fiscal policy. Fiscal incentives influence entrepreneurship development (Sangram, 2009). These incentives not only stimulate the economic environment but also create a favourable climate for entrepreneurial growth. Entrepreneurship activities serve to promote economic growth (Acs \& Armington, 2006). Although the relative effectiveness of both monetary and fiscal policies in boosting growth is different across countries, both policies significantly influence entrepreneurship which suggests that they should be jointly used to drive. However, poor public policy undermines entrepreneurial behaviour and reduces public welfare (McCaffrey, 2015). Public policy should therefor take crucial steps to promote entrepreneurship by creating conducive business environments, provide financial support for entrepreneurship activities and spend more on infrastructural development.

\section{References}

Acs, Z. J. \& C. Armington, C. (2006). Entrepreneurship, geography and American economic growth. Cambridge: Cambridge University Press.

Adenikinju, A. F. (2005). African imperatives in the new world trade order: Country case study of the manufacturing sector in Nigeria. In Ogunkola O. E. \& Bankole A. (eds.), Nigeria's imperatives in the new world trade order. Nairobi/Kenya: Africa Economic Research Consortium; Ibandan/Nigeria: Trade Policy Research and Training Programme.

Agboli, M. \& Ukaegbu, C. C. (2006). Business environment and entrepreneurial activity in Nigeria: Implications for industrial development. Journal of Modern African Studies, 44(1), 1-30.

Agenor, P. R. \& Moreno-Dodson, B, (2006). Public infrastructure and growth: New channels and policy implications. World Bank Policy Research Working Paper No. 4064. World Bank.

Ahmad, N. \& Hoffman, A. (2007). A framework for addressing and measuring entrepreneurship. Paris: Entrepreneurship Indicators Steering Group.

Ascharer, D. A. (1989). Does public capital crowd out private capital? Journal of Monetary Economics, 24(2), 171-188.

Baumol, William J. (1990).“Entrepreneurship: Productive, Unproductive, and Destructive," Journal of Political Economy 98, no.5: 893-919.

Boyd, J. H. \& Champ, B. (2003). Inflation and financial market performance: What have we learnt in the last ten years? Federal Reserve Bank of Cleveland Working Paper 03-17. Cleveland: Federal Reserve Bank of Cleveland.

Braconier, H. \& Holden, S. (2004). Fiscal policy in the OECD: Measurement and cyclical adjustment, mimeo.

Dennis Jr., W. J. (2005). Entrepreneurship, small business and public policy levers. Journal of Small Business Management, 29(2), 149-162.

Edame, G. E. \& Fonta, W. M. 2013). The impact of government expenditure on infrastructure in Nigeria: A cointegration \& error correction specification. International Journal of African and Asian Studies, 3, 50-63.

Harper, D. A. (2003). Entrepreneurship and the market process: An enquiry into the growth of knowledge. London and New York: Routledge. 
McCaffrey, M. (2015). Economic policy and entrepreneurship: Alertness or judgment? In Bylund, P. L. \& McCaffrey, M. (eds.), The next generation of Austrian economics: Essays in honor of J. T. Salerno. Auburn, AL: Mises Institute.

Monacelli, Tommaso (2004): ilnto the Mussa Puzzle: Monetary Policy Regimes and theReal Exchange Rate in a Small Open Economy, îJournal of International Economics,62, 191-217

Ncube, M. (2015). Economic growth, entrepreneurship and the business environment in Africa. Working Paper No. 30. Johannesburg: University of the Witwatersrand.

Sanchez-Robles, B. (1998). Infrastructural investment and growth: Some empirical evidence. Contemporary Economic Policy, 16(1), 98-108.

Shin, Y., Yu, B. \& Greenwood-Nimmo, M. J. (2014). Modelling asymmetric cointegration and dynamic multipliers in a nonlinear ARDL framework. In Sickles, R. C. \& Horrace, W. C. (eds.), Festschrift in honor of Peter Schmidt: Econometric methods and applications (pp. 281-314). New York (NY): Springer Science \& Business Media.

Sims, C. A. (1994). A simple model for study of the determination of the price level and the interaction of monetary and fiscal policy. Economic Theory, 4(3), May, 381-399.

Taylor, Lance (2004). Exchange Rate In Determinacy in Portfolio Balance, Mundell-Fleming, and Uncovered Interest Rate Parity Models. Cambridge Journal of Economics 28: 205-227. 